See discussions, stats, and author profiles for this publication at: https://www.researchgate.net/publication/316654332

\title{
New Business Activity and Employment Dynamics in the Inner City: The Case of Phoenix Arizona
}

Article in Urban Affairs Review · May 2017

DOI: $10.1177 / 1078087417709600$

CITATION

1

2 authors:

Elizabeth A. Mack

Michigan State University

76 PUBLICATIONS 1,272 CITATIONS

SEE PROFILE
READS

212

Kevin Credit

National University of Ireland, Maynooth

15 PUBLICATIONS 69 CitATIONS

SEE PROFILE 
New Business Activity and Employment Dynamics in the Inner City: The Case of Phoenix Arizona

Elizabeth A. Mack

Department of Geography, the Environment and Spatial Sciences

Michigan State University

emack@msu.edu

Kevin Credit

Department of Geography, the Environment and Spatial Sciences

Michigan State University

creditke@msu.edu 


\begin{abstract}
Inner city revitalization efforts centered on fostering new business activity are controversial because they assume that the job creating capacity of new businesses is capable of impacting aggregate employment levels in inner city neighborhoods. Given this controversy, this paper examines the link between new business activity and inner city employment growth in Phoenix, Arizona. Analytical results highlight job creation from new business activity but a net negative association between new business activity and employment growth stemming from the loss of jobs from large employers in inner city neighborhoods. This relationship highlights that encouraging new business activity is not necessarily a bad idea for local residents and customers, but should not be viewed as a panacea for all inner city problems. Instead, new business activity should be viewed as one component of multifaceted initiatives to revitalize inner city neighborhoods.
\end{abstract}




\section{Introduction}

Despite the implementation of a variety of strategies for improving inner city neighborhoods, the economic and social situation of these areas remains dire (Imbroscio 2012). Small business development strategies have been suggested as one avenue for revitalizing inner city neighborhoods, but not without controversy. Although several studies have found small businesses to be job creators (Birch 1987; Kirchhoff and Phillips 1988; Von Bargen, Freedman, and Pages 2003; Baptista, Escária, and Madruga 2008), more recent work suggests that only a small proportion of new businesses are responsible for the majority of job creation (Birch 1987; Gittell and Thompson 1999; Nightingale and Coad 2014). In an inner city context, the ability of these businesses to create jobs and rescue inner city residents from poverty is doubtful (Bates 1997; Gittell and Thompson 1999) given the multitude of supply and demand issues in low income communities that impede entrepreneurial activity (Acs and Kallas 2008).

While prior work has suggested that small business development strategies are a viable means of infusing inner city areas with new business activity that will hire people from nearby neighborhoods (Porter 1995; Porter 1997), the extent to which businesses create jobs remains an understudied aspect of the inner city revitalization literature. This lack of study likely stems from a lack of fine grained business data (Gittell and Thompson 1999). Given the need for more research about business activity in inner city areas and their job creation capacity, this paper will leverage a fine grained point dataset for businesses in Phoenix, Arizona to analyze whether new businesses in inner city areas create jobs, and the extent that jobs created by these businesses are linked to inner city employment dynamics as a whole. The results of this analysis will answer three questions: First, to what extent is new business activity in inner city locations associated 
with positive employment growth? Second, to what extent does this job creation associated with aggregate employment trends in inner city areas? Third, what other characteristics of inner city neighborhoods are associated with employment growth over time?

Analytical results highlight that in Phoenix, new business activity is negatively associated with employment growth for inner city neighborhoods. Interestingly, this net negative relationship stems from the closure of major employers in inner city locations, which obscures new jobs created by new business activity. These findings highlight that there is value to encouraging new business activity in inner city areas, which create jobs and provide goods and services for local residents. However, new businesses alone should not be viewed as a panacea for all inner city problems. Results also highlight that aggregate analyses of the inner city may be insufficient to decompose nuanced trends in inner city employment dynamics. Thus, the encouragement of new business activity should be viewed as one component of larger, multifaceted initiatives to revitalize inner city neighborhoods with detailed, neighborhood specific efforts to evaluate the success of these initiatives.

\section{Small Business and Inner City Redevelopment}

The idea that small businesses are a critical component of inner city neighborhood revitalization efforts can be linked to prior studies that highlight the promise of small businesses for creating jobs (Acs and Kallas 2008), overcoming social exclusion, and promoting economic growth (Blackburn and Ram 2006). However, the extent of social and employment impacts, and the proper method for small business oriented economic development strategy implementation are subject to much debate in the literature. Nowak (1997) suggests that local ventures should be pursued because they can help rebuild the physical assets and tax base of the community, create 
linkages between neighborhoods and companies outside of the community, and create jobs to build the skills and employment opportunities for inner city workers. Inner city businesses can also help low to moderate income neighborhoods integrate their residents in business-related opportunities throughout their component metropolitan areas (Gittell and Thompson 1999). Prior studies have also found that minority owned businesses employ more minority workers than do White owned firms (Bates 1997). This suggests that small business development strategies might increase minority employment. Studies have also noted that minority owned businesses may induce additional business activity and that small business economic development strategies may be a mechanism for increasing the number of minority owned businesses in cities (Gittell and Thompson 1999). Proponents of small business development strategies also note that cities are excellent incubators for small and medium sized firms (Glaeser 1998; Audretsch 2002) and inner city locations are ideal for small business activity. Not only do inner city locations have cheaper, older structures that are ideal for new businesses (Jacobs 1961), but they are also strategically located, are a source of local demand for business products, and are a source of underutilized human resources (Porter 1995).

Despite these benefits of inner city areas and the many benefits that small businesses can bestow on inner city residents, several studies cast doubt on the power of small business development strategies alone in ameliorating the many structural disadvantages that plague inner city residents (Blackburn and Ram 2006). These studies highlight that small businesses are likely to impact individuals on the cusp of social and economic disadvantage instead of helping the truly disadvantaged (Gittell and Thompson 1999). Studies also note that small businesses are more likely to pay lower wages and offer fewer benefits than large firms, which have more job security and skill improvement opportunities (Atkinson and Storey 1994). There are also a host 
of supply and demand issues in low income communities that impede new business activity (Acs and Kallas 2008). These issues include a lack of demand for products because residents lack purchasing power and savings. Residents also lack skills, experienced and successful role models, and the time and resources needed to build social networks and capital (Curran and Blackburn 1994; Storey 1994; Welter, Trettin and Neumann 2008). This list of impediments makes it difficult to start businesses. If residents do start new businesses, they tend to do so in market segments with low barriers to entry. These low barriers encourage many people to start businesses, which increases the level of competition for new businesses and lowers growth prospects (Acs and Kallas 2008). The potential for high levels of competition in specific industries and/or market segments also limits the long-term survival prospects of inner city startups.

While small businesses are recognized for their job creating capacity (Birch 1987) more recent studies have suggested that only a small proportion of all businesses create the bulk of new jobs (Gittell and Thompson 1999; Nightingale and Coad 2014). These high growth firms are known as "gazelles" and several studies have found it is these businesses, rather than all small businesses, that are the source of new jobs (Storey 1994; Delmar, Davidsson, and Gartner 2003). In fact, research about gazelles has even suggested dividing new businesses into two groups: high performing gazelles and low performing firms or "muppets" (Nightingale and Coad 2014). These studies call into question the current public policy perspective on fostering a large quantity of new business activity (Nightingale and Coad 2014), and suggest instead that the policy emphasis be revised to focus on the quality of new firms (Smallbone, Baldock and Burgess 2002; Santarelli and Vivarelli 2007). However, studies that support the current public policy emphasis highlight that job creation comes from both new firms and gazelles (Henrekson and Johansson 
2010). They also emphasize the findings of prior studies that firm churn and turbulence boost job creation (Bartelsman, Scarpetta, and Schivardi 2005; Brown, Haltiwanger, and Lane 2006;

Fogel, Morck, and Yeung 2008). It has also been suggested that increasing the number of new firms in the economy increases the opportunity for churn, which in turn, increases the odds of creating more gazelles in the future (Henrekson and Johansson 2010).

Recent work on employment trends in inner city neighborhoods highlights that some, but not all, metropolitan areas have inner cities that are competitive at generating employment growth (Hartley, Kaza, and Lester 2016). While important, this prior work does not analyze the link between employment trends and new business activity within inner city locations. National level studies likely obscure important spatial employment dynamics in inner city neighborhoods, which highlights a need for more case-specific studies that examine these dynamics within the inner city.

\section{Study Area}

Given the lack of empirical evidence about the job creating capacity of new business activity in inner city areas, this study uses fine-grained point level data to analyze whether new businesses in inner city areas create jobs. The study also analyzes the linkages between new business employment creation and employment dynamics, while developing a rich context about the locational patterns and industrial profile of these new businesses within the inner city of Phoenix Arizona. Phoenix represents an important case study for this type of analysis because it has not been highlighted in prior work as a competitive metropolitan area in inner city job creation (Hartley, Kaza, and Lester 2016). Downtown Phoenix has also struggled to 
maintain it vibrancy and is recognized as one of the more sprawling, least sustainable metropolises in the United States (Ross 2011).

This legacy of sprawl dates back to the 1940's when the decentralization of economic activity from the downtown core began (O’Shea 2013). Today, Phoenix is characterized by lowdensity zoning (O’Shea 2013) and large, big-footprint structures (Ford 2003). In fact, Phoenix receives low downtown rating scores, similar to Atlanta, due to several big-footprint, big-box structures and a lack of human-scaled architecture (Ford 2003). The metropolitan area has also experienced an increased incidence of poverty that rivals poverty trends in the country's largest metropolitan areas such as New York, Detroit, and Chicago (Sunnucks 2014). Since 1990, 57 neighborhoods in the Phoenix area have become high poverty areas with more than 96,700 residents living in these declining neighborhoods (Sunnucks 2014).

Due to the outward expansion of the metropolitan area, and the subsequent departure of economic activity from the downtown core, city officials have instituted a variety of initiatives to revitalize the downtown area. These initiatives have ranged from the Genomics bioscience initiative in 2002 (City of Phoenix 2004), the Phoenix Copper Square District in 2004 (City of Phoenix 2004), the creation of a downtown branch of Arizona State University in 2006 (AZ Central 2014), and the construction of a light rail system in 2008 (AZ Central 2014). These initiatives, paired with arts and culture-based economic development activities along Roosevelt Row, are beginning to have an impact on business activity and foot traffic in the downtown area (Pela 2016). While the number of initiatives makes it difficult to isolate the impact of any one effort in particular, the goal of this study is to examine whether new businesses in inner city locations created jobs, and the link between these job creation trends and aggregate inner city employment dynamics between 2000 and 2009. 
Figure 1 provides a regional context for inner city block groups, highlighting the major cities that comprise the Phoenix metropolitan area, as well as select neighborhoods within the city limits of Phoenix in 2000. This map also shows the location of inner city block groups within the city of Phoenix and the larger metropolitan area. It was constructed by georeferencing a Phoenix urban village map obtained from the Planning and Development Department of the City of Phoenix (City of Phoenix 2014) with city boundary shapefiles obtained from the Arizona State University GIS Data Repository (ASU 2014) and a block group boundary files for 2000 from the National Historical Geographic Information System (NHGIS) (Minnesota Population Center 2011). Within the city limits of Phoenix, Camelback East contains many upscale homes, while the Encanto area contains several historic homes from the World War II-era. The central city area of Phoenix contains Washington, Fillmore, and Van Buren streets and is the location of the downtown campus of Arizona State University which opened in 2006 (Terrill 2011). The majority of block groups identified as inner city block groups are found south of downtown. These block groups are located primarily in the low-income neighborhoods of South Mountain, Laveen, Estrella, and Maryvale.

\section{Figure 1 here}

\section{Identifying Inner City Areas}

While there is little consensus as to formal statistical definitions of inner city environments, (Hartley, Kaza, and Lester 2016), inner city areas are generally defined as immigrant-intensive, low-income neighborhoods adjoining or nearby central city locations (Harrison and Glasmeier 1997). Based on this definition, inner city areas within the Phoenix 
metropolitan area are defined as block groups that fall within the boundaries of the city of Phoenix and have per capita personal income that is within the lower quartile of Phoenix metropolitan area per capita income. In the year 2000, this corresponds to per capita personal income of less than $\$ 13,798$. This definition of the inner city is in line with prior work which defines inner city areas based on their proximity to the central city (Harrison and Glasmeier 1997) and income (Porter 1997; Hartley, Kaza, and Lester 2016).

In 2000 there were 370 inner city block groups, which represents about $17.6 \%$ of all block groups within the metropolitan area and 35\% of block groups within the city of Phoenix. Figure 1 illustrates the location of inner city block groups within the greater Phoenix metropolitan area and highlights that these block groups are concentrated generally in south Phoenix. This portion of Phoenix is an area of concentrated poverty, as well as crime and racial conflict. It is a primarily Hispanic portion of the city with limited educational and economic resources (Bruner and Tirmizi 2010) and a heavy concentration of public housing (Phoenix Revitalization Corporation 2010). In the mid-2000's violence between rival Hispanic and Black gangs escalated over efforts to control the drug trade in the area (de Uriarte 2008).

Table 1 presents some basic demographic and socio-economic information about the inner city block groups identified compared to non-inner city block groups in the rest of the metropolitan area. This table highlights that inner city block groups are more densely populated, primarily Hispanic areas with lower levels of educational attainment than non-inner city block groups. Rents in inner city block groups are cheaper than non-inner city block groups and the housing stock older. There is also a large labor pool in these areas, as indicated by the percentage of people between the ages of 16 and 64 . These characteristics correspond to central city 
advantages highlighted by both Jacobs (1961) and Porter (1995): older and cheaper housing stock, and an available pool of labor.

\section{Table 1 here}

\section{Methodology}

Data about employment and new business activity were obtained from the National Establishment Time Series Database (NETS). This is a Dun and Bradstreet derived, point-level dataset that contains information about establishments and employment in the Phoenix metropolitan area on an annual basis between 1990 and $2010^{1}$. Given the high-resolution information provided by this dataset, NETS data have been used in a variety of studies (Neumark, Zhang, and Wall 2005; Neumark, Wall and Zhang 2011; Kroll, Lee, and Shams 2010). These data are also particularly valuable for studies of new business creation and associated employment trends because they include comprehensive information about part-time workers, contract and temporary employees, and persons that hold multiple jobs than other government sources of employment data including County Business Patterns (CBP) and the Quarterly Census of Employment and Wages (QCEW) from the Bureau of Labor Statistics (Kunkle 2011). In this regard, studies have noted that this data source does a better job of reporting employment data for small businesses that employ between 1 and 9 people (Neumark, Zhang, and Wall 2005), which is important for the purposes of this study.

Aside from the fine-grained spatial resolution of these data, NETS are also comprehensive in their coverage of business characteristics and contain over 100 variables about covered businesses (Walls \& Associates 2013). In the context of this study, the information 
about industry characteristics from the North American Industrial Classification System (NAICS), the opening and closing date of each business, and establishment employment are particularly important. Using this information, it is possible to distinguish between new businesses in a given year and existing businesses based on information about the start date. Once new businesses were identified from their start date, they were aggregated to the block group level to obtain the count of new businesses and associated employment from these businesses in each block group.

The NETS database also reports annual employment for each business in Phoenix. This information was used to construct the dependent variable in this study: the change in employment by place of work between 2000 and 2009. Employment levels in block groups were computed as the sum of all employment from existing businesses within a particular block group, as indicated in the database.

\section{Model Covariates}

In addition to information about employment and new business activity at the block group level, a suite of other covariates is included in the econometric models that will be described in the next section. These variables provide information on the demographic, socioeconomic, business, and land-use characteristics of block groups, and are defined in Table 2. Appendix A contains the descriptive statistics for these variables.

\section{Table 2 here}


Race and ethnicity variables are included to characterize the demographic profile of block group residents. These variables are in the form of location quotients, which are designed to identify whether block groups contain higher concentrations of Black and Asian residents than would be expected for the metropolitan area as a whole. To describe the age of existing housing stock, median year structure built is included in the models.

Aside from controlling for the characteristics of residents and the housing stock of block groups, two variables are included to account for different kinds of business activity. To construct these variables, information about the NAICS industry classification of existing businesses was extracted to calculate location quotients for manufacturing and retail establishments to capture concentrations of manufacturing and retail activity within block groups. This information, in addition to land-use data, help us understand the types of business and land uses across the metropolitan area.

Information about land-use within block groups is derived from parcel land-use data obtained from the Maricopa Association of Governments (MAG). These data were aggregated to block groups to obtain the amount of particular types of land-use in square miles. Vacant developable land-use is included in the model as a measure of available space for new businesses. Multi-family housing units are also included to provide some resolution on housing composition. While it would be desirable to include more measures of land-use and housing stock types, multicollinearity precluded the use of more land-use variables in the models.

\section{Model Specification}

In order to analyze whether new businesses are positively associated with job growth in inner city areas, a series of models was estimated for the 2000-2009 study period. These models 
are based on block group data because they approximate neighborhoods within urban areas (Buron and Patrabansh 2008; Lee et al. 2008). To create the dependent variable - employment by place of work between 2000 and 2009 - point data from NETs with associated employment information was aggregated to Census block groups. In this aggregation process, it is important to note that data were parsed to ensure that only existing businesses were included in these counts to distinguish between established businesses and new businesses for the study years of interest.

The regression models estimated in this paper are a variation of a growth regression, which builds on prior work examining inner city employment growth from a national perspective (Hartley, Kaza, and Lester 2016). This type of model is ideal for the present study because it reflects how the initial conditions of block groups in the year 2000 impact the change in employment activity several years later. In this respect, it takes into account lagged effects between business creation and employment growth in later years which take time to be realized. The use of a nine-year time lag also mitigates direct endogeneity between new business activity and employment change. Three versions of growth regression models are estimated: one based on ordinary least squares (OLS) and two spatial models to capture possible spatial effects in the data sample of interest. The basic specification of the growth regression model is as follows:

iec $_{\mathrm{i} 2000-2009}=\alpha+\lambda$ newbusinesses $\mathrm{s}_{\mathrm{i} 2000}+\beta \mathbf{X}_{2000}+\mu$

IEC corresponds to the change in the natural logarithm of employment within inner city block groups between 2000 and 2009. Beta ( $\beta$ ) corresponds to a vector of regression coefficients estimated for the matrix of control variables $(\mathbf{X})$ which are described in Table 2. Lambda $(\lambda)$ 
corresponds to the regression coefficient on the variable for new business activity. $\mathrm{Mu}(\mu)$ is an error term that is identically and independently distributed (iid).

To account for spatial spillover effects, two variations of the model specified in equation (1) were also estimated. The first variant, which is specified below in equation (2), is a spatial lag model. This model accounts for spatial spillovers in employment change. In other words, it accounts for similar employment changes in areas that border each observation, as specified by a spatial weights matrix. In the models estimated for this study, a three nearest neighbor weights matrix is used. This type of weights matrix ensures that each observation has neighbors, in order to account for the discontinuous nature of the inner city block groups in Phoenix (shown in Figure 2). In a spatial lag model, each of the independent variables are also indirectly lagged, since the model specifies that changes in employment activity are a function of these independent variables. Thus, by lagging the dependent variable, this model also lags all of the independent variables specified in Table 2:

iec $_{\text {i2000-2009 }}=\alpha+\rho \mathbf{W i e c}$ i2000-2009 $+\lambda$ newbusinessesi2000 $+\beta \mathbf{X}_{2000}+\mu$

In equation (2), IEC corresponds to the change in the natural logarithm of employment within inner city block groups between 2000 and 2009. Rho ( $\rho)$ represents the coefficient for the spatial lag of employment change, $\mathbf{W}$ is a nearest neighbor weights matrix, and $\beta$ corresponds to the vector of regression coefficients estimated for the control variables described in Table 2. Lambda $(\lambda)$ is the regression coefficient on the variable for new business activity. $\mathrm{Mu}(\mu)$ is an error term that is identically and independently distributed (iid). 
While valuable, equation (2) deals primarily with spatial autocorrelation in employment changes. In the context of this study, perhaps a better question to ask is whether spatial effects or new business activity in neighboring block groups of inner city locales - is associated with employment changes in later years. To answer this question, a growth regression model with a spatial lag of new business activity was also estimated. The specification of this spatial model is as follows:

iec $_{\mathrm{i} 2000-2009}=\alpha+\lambda$ newbusinesses $_{\mathrm{i} 2000}+\delta \mathbf{W}$ newbusiness $\mathrm{i}_{2000}+\beta \mathbf{X}_{2000}+\mu$

In this model, IEC corresponds to the change in the natural logarithm of employment within inner city block groups between 2000 and 2009. Lambda $(\lambda)$ is the regression coefficient on the variable for new business activity, $\mathbf{W}$ is a nearest neighbor spatial weights matrix and delta $(\delta)$ corresponds to the coefficient estimate of the spatial lag in new business activity. Beta ( $\beta$ ) represents the regression coefficients for the control variables in Table 2 and $\mu$ is an error term that is identically and independently distributed (iid).

These models are designed to test the hypothesis that new business activity is associated with employment growth. This is based on the idea that as new businesses created in 2000 grow, they will hire more people, which will positively influence employment levels in later years. Aside from the job creating capacity of 2000 new starts, there are other reasons to believe new businesses in 2000 will positively influence employment in later years. One possibility is that business activity in 2000 may induce demand for more products and services in the area, which prompts more businesses to open nearby. Another possibility, is that new business activity may 
have a signaling impact about the vitality of particular neighborhoods to prospective businesses. This positive signal may also attract additional business activity to the neighborhood.

\section{Results}

Before proceeding to a discussion of model results, spatial patterns and the industrial profile of new business activity in 2000 are analyzed. Figure 2 shows a kernel density map that highlights the intensity of new business activity in 2000, and shows that new business activity is most intense in the cities of Phoenix, Scottsdale, and Tempe. There is also noticeable new business activity in Mesa, Chandler, and Gilbert to the east of Tempe. Within the City of Phoenix, $26.9 \%$ of all new business activity is located in inner city locations, including the North Mountain, Camelback East, Encanto, and Central City neighborhoods. There is also noticeable new business activity to the north of these neighborhoods bordering the city of Scottsdale.

\section{Figure 2 here}

In terms of the industrial profile of new business activity, Table 3 contains the breakdown of new and existing business activity by two-digit North American Industrial Classification System (NAICS) in 2000. The table highlights that while inner city and non-inner city businesses share some industrial similarities, there are also notable differences. For example, inner city locations have more new businesses engaged in retail, while non-inner city locations contain a higher percentage of new businesses in Professional, Scientific and Technical Services (NAICS 54) and Finance and Insurance (NAICS 52). In terms of existing business activity, in 2000, inner

city areas contained more retail and transportation businesses, while non-inner city areas 
contained higher levels of services. By 2009, however, the difference in industry mix between inner city and non-inner city locations has changed even more. This difference is particularly notable in the higher-skilled services categories of finance and insurance, as well as professional, scientific and technical services-this is an industry that includes occupations in engineering, science, and consulting.

\section{Table 3 here}

\section{Regression Results}

Table 4 shows the regression model results for the 2000-2009 study period. Model one contains the ordinary least squares results. Model two contains the ordinary least squares estimates for a similar model, with a spatial lag of new business activity included. As described previously, this lag is designed to capture spillover effects in new business activity in nearby block groups. Models one and two were estimated with heteroskedastic robust standard errors. Model three contains the results of a spatial lag model estimated with standard errors robust to heteroscedasticity and spatial autocorrelation not captured via the spatial lag term (HAC errors). In model three, a lag of new business activity is not included because this variable is indirectly lagged as a function of the spatial lag specification already. Instead, the significant spatial lag in this model highlights the need to capture spatial spillovers in employment change for the 20002009 study period. The model indicates a negative relationship between new business activity and employment.

\section{Table 4 here}


Beyond the results for new business activity, other covariates from model two highlight factors critical to understanding employment changes within inner city areas. Block group characteristics that had a positive association with inner city employment change include more space dedicated to multifamily land-use, business specialization, higher densities of people, and also more residents working in management and professional occupations. Combined, these individual characteristics highlight that inner city locales with higher concentrations of localized pools of qualified labor were more likely to experience employment gains. These results also show that business specialization, rather than diversity, was a factor behind employment gains over this period.

\section{Inner City Employment Dynamics}

While model results reveal a net negative relationship between new business activity and employment change on average, this finding also obscures important block group dynamics that are worthy of some elaboration. A closer examination of employment dynamics within the inner city reveals that not all block groups lost jobs. In fact, of the 370 block groups in the inner city, the majority $(70.5 \%)$ created 35,077 jobs, while a smaller percentage of block groups $(28.4 \%)$ are responsible for a loss of 73,188 jobs. Four block groups neither gained nor lost jobs. Figure 3 contains the distribution of block groups that gained and lost jobs within the inner city.

\section{Figure 3 here}

An analysis of employment dynamics in these block groups reveals that the job losses come from a combination of business closures and business contractions (business that remained 
opened but cut employees). A detailed look at new business activity also highlights that many small businesses opened in the inner city throughout this ten-year time period. These business are small in terms of the people employed, so, while small business openings in the inner city did in fact create jobs, these new jobs were unable to counterbalance the jobs lost from business closings and business contractions. While this finding is specific to Phoenix's inner city, it reflects the continuation of a national trend in the relationship between job growth and new business starts; since 2000, job growth has been relatively stagnant nationally, while the number of new business starts has increased greatly (Walls \& Associates 2012).

Aside from the type of businesses opening in the inner-city, urban design issues within inner-city locations, which discourage pedestrian activity, could also be hampering business visibility and long-term viability. Figure 4 presents a recent satellite image of one of the inner city block groups from 2000 that contains many of Phoenix's central business district (CBD) functions and that has been the location of a variety of revitalization efforts including the construction of Chase Field in 1996 and the installation of the light rail in 2008. In this block group, 73 new businesses started in 2000 and there were 344 (net) additional businesses created between 2000 and 2009. An in depth examination of businesses in this block group highlights a net loss of 11, 701 jobs between 2000 and 2009. These job losses stem from a complex interplay of surviving business contraction which were responsible for 8,753 job losses, the loss of 12,748 jobs from business closings, and 9,800 jobs created from new business activity. Thus, even though there are 344 more businesses in the block group in 2009 than there were in 2000 , the small scale of these businesses, in terms of jobs, was insufficient to counteract employment losses from the contraction and closing of existing larger businesses. 


\section{Figure 4 here}

There are also some important differences in the characteristics of block groups that gained jobs and those that lost jobs. Table 5 displays the results of an analysis of variance (ANOVA) conducted to understand differences between these two sets of block groups. The ANOVA analysis is different from the regression results in two ways. One, it compares two different sets of block groups, as opposed to evaluating all inner city block groups together. Two, it permits the inclusion of additional variables that were not possible in the regression analysis because of multicollinearity and/or the issue of confounding variables. This table highlights that block groups with job gains had fewer manufacturing businesses, more residents that were employed in management and professional occupations, and less industrial diversity than block groups with job losses. Job-gaining block groups also had less multifamily housing and higher median contract rents. There were no statistical differences in the demographic profile of residents between these sets of block groups.

\section{Table 5}

\section{Sensitivity Analysis}

In addition to the consideration of spatial effects, a series of sensitivity analyses were conducted to evaluate the robustness of model results. One of these sensitivity analyses involved an evaluation of the impact of the terminal year of the study period on model results. This is important because the initial year of the study period falls at the beginning of the dot.com boom and associated economic expansion at the turn of the millennium, while the end year of the study 
(2009) comes directly after the great recession of 2008. This means that employment at the end of the study period might be lower than 2000 as a result of the 2008 recession, rather than local employment dynamics. To address this possible impact on model results, two alternate end years are examined (2005 and 2007) and associated models estimated, with the exact specification of the models presented in Table 4. These end years were selected because they coincide with a period of relative prosperity (rather than decline) from a macroeconomic perspective. They also coincide with economic development initiatives in Phoenix specifically, which were discussed earlier in the paper. The results of this sensitivity analysis can be found in Appendices B and C. Overall, this table highlights that the terminal year of the study period did not significantly impact model results.

Two additional sensitivity analyses were also conducted to ascertain the impact of alternate Census geographies, and sources of employment data on model results. Models were re-estimated using Census tract data, as well as employment by place of residence from the Census, instead of employment by place of work which is the information provided by the NETs database. Both modifications to model results did not change the robust negative relationship between business starts and changes in employment. A final set of sensitivity analyses were conducted to evaluate the robustness of results to the weights matrix used in the spatial models in Table 4. This portion of the sensitivity analysis revealed that the model results were also robust to different numbers of nearest neighbors used in the spatial weights matrix.

\section{Discussion and Conclusion}

The uncoupling of economic activity in cities (Mallach 2015) and subsequent creation of an urban underclass (Imbroscio 2012; 2016), highlight the need for strategic thinking about inner 
city revitalization efforts. New business activity has been offered as a means of revitalizing inner city neighborhoods (Porter 1995; Porter 1997). This proposition rests on two important assumptions however. First, that new businesses create jobs, and second, that this job creation is capable of impacting aggregate employment levels in the inner city. Given these assumptions about inner city business activity and job creation, the goal of this article was to examine the linkage between new business activity and inner city employment growth in Phoenix, Arizona. While no causal statements can be made from the analytical results, the findings did reveal several pertinent facets of inner city businesses activity.

The regression analysis highlighted a net negative relationship between new business activity and employment growth between 2000 and 2009. This net effect, however, obscures complex employment dynamics within block groups that include business openings, contractions, and deaths. A more in-depth analysis of these dynamics reveals that the small number of jobs created by new businesses were insufficient to counteract business contractions and closures. These results speak to the need for tracking and working with existing businesses in inner city locations, since the net negative association in this analysis stems from business closures and contractions. Analytical results also suggest that the attraction of business relocations to the downtown area could also help counteract the loss of jobs in inner city areas. In fact, local observers have commented that while downtown Phoenix has experienced a unique renaissance in recent years, it lacks the presence of large companies and corporate headquarters characteristic of other downtown areas across the U.S. (Talton 2017).

That said, it is necessary to note that these results are case-specific and do not generalize to other metropolitan areas. The nuanced job dynamics in inner city locations highlighted in this paper also argue for in-depth neighborhood-level analyses of new business activity and inner city 
employment. These nuances suggest that aggregate analyses of the inner city are likely to miss important dynamics that merit targeted policy attention, particularly locales that are isolated from a socio-economic and spatial perspective. Another extension to this study could conduct interviews of new business owners in order to understand the hiring process for employees and the extent that the employment generated by new businesses sources inner city residents. This type of future work is important, since it is not possible to determine the source of business employment from secondary data sources.

The results of the present study are also not meant to suggest that business activity is the only solution to the plight of urban residents; workforce training to upgrade skills and coordinated efforts that involve community based organizations (CBOs), economic development, and even private entities are needed to revitalize resource-rich but underutilized populations in inner city environments. As noted in prior work, community-based organizations should play a fundamental role in these efforts (Bates 1997; Harrison and Glasmeier 1997; Gittell and Thompson 1999), particularly given the failure of neoliberal policies to economically mobilize a growing urban underclass (Imbroscio 2012; 2016). As highlighted in this study, new businesses do locate in inner city locations and create jobs. However, multifaceted efforts above and beyond the encouragement of new venture creation are necessary to improve the economic activity and vibrancy of inner city neighborhoods. 


\section{End Notes}

1. These are the dates for which information is recorded. There is a one-year time lag between the time information is recorded and information is reported. Thus, data recorded in year 2010 actually reflect information reported the year prior (2009). From this point forward, the reported year will be used in the discussion of data and results. 


\section{References}

Acs, Zoltan and Kadri Kallas. 2008. "State of Literature on Small-to Medium-Sized Enterprises and Entrepreneurship in Low-income Communities." In Entrepreneurship in Emerging Domestic Markets, edited by Glenn Yago and James R. Barth, 21-45. Santa Monica: Springer.

Arizona State University (ASU). 2014. "ASU GIS Data Repository.” https://lib.asu.edu/GIS/repository. (accessed January 23, 2016).

Atkinson, John and David Storey. 1994. "Small Firms and Employment." In Employment, the Small Firm and the Labour Market, edited by John Atkinson and David Storey, 1-27. New York: Oxford University Press.

Audretsch, David. 2002. "The Dynamic Role of Small Firms: Evidence from the U.S. Small Business Economics, 18: 13-40. Accessed April 3, 2017. doi: 10.1023/A:1015105222884.

Bates, Timothy. 1997. "Response: Michael Porter's Conservative Urban Agenda Will Not Revitalize America's Inner Cities: What Will?” Economic Development Quarterly, 11: 39-44. Accessed April 3, 2017. doi: 10.1177/089124249701100104.

Baptista, Rui, Vítor Escária, and Paulo Madruga. 2008. "Entrepreneurship, Regional Development and Job Creation: The Case of Portugal." Small Business Economics 30: 49-58. Accessed April 3, 2017. doi: 10.1007/s11187-007-9055-0.

Bartelsman, Eric, Stefano Scarpetta, and Fabiano Schivardi. 2005. "Comparative Analysis of Firm Demographics and Survival: Evidence from Micro-Level Sources in OECD Countries." Industrial and Corporate Change 14: 365-391. Accessed April 3, 2017. doi: https://doi.org/10.1093/icc/dth057. 
Birch, David. 1987. Job Creation in America. New York: The Free Press.

Blackburn, Robert and Monder Ram. 2006. "Fix or Fixation? The Contributions and Limitations of Entrepreneurship and Small Firms to Combating Social Exclusion." Entrepreneurship and Regional Development 18: 73-89. Accessed April 3, 2017. doi: http://dx.doi.org/10.1080/08985620500419566.

Brown, Clair, John Haltiwanger, and Julia Lane. 2006. Economic Turbulence: Is a Volatile Economy Good for America? Chicago: University of Chicago Press.

Bruner, Charles and Syed Tirmizi. 2010. "Young Children of South Phoenix: Ensuring Healthy Growth and Development." AZ Health Survey. http://bit.ly/29jbgWE . (accessed January 23, 2016).

Buron, Larry and Satyendra Patrabansh. 2008. “Are Census Variables Highly Correlated with Housing Choice Voucher Holders' Perception of the Quality of Their Neighborhoods?” Cityscape 10: 157-183. Accessed April 3, 2017.

City of Phoenix. 2014. "Village Planning Committees.” http://1.usa.gov/299ULtx. (accessed January 23, 2017).

City of Phoenix. 2004. "Downtown Phoenix: A Strategic Vision and Blueprint for the Future." December 14, 2004. http://bit.ly/2jH4Bcv. (accessed January 23, 2017).

Curran, James, and Robert Blackburn. 1994. Small Firms and Local Economic Networks: The Death of the Local Economy? London: Paul Chapman.

Delmar, Frédéric, Per Davidsson, and William B. Gartner. 2003. "Arriving at the High-Growth Firm." Journal of Business Venturing 18: 189-216. Accessed January 23, 2017 
de Uriarte, Richard. 2008. "The gang war in south Phoenix. Residents and police are fighting back, but are they gaining ground?" The Arizona Republic. October 12, 2008. http://bit.ly/29gZfzc. (accessed January 23, 2017).

Fogel, Kathy, Randall Morck, and Bernard Yeung. 2008. "Big business stability and economic growth: Is what's good for General Motors good for America?" Journal of Financial Economics 89: 83-108. Accessed April 3, 2017. doi: http://dx.doi.org/10.1016/j.jfineco.2007.06.004.

Glaeser, Edward. 1998. “Are Cities Dying?” The Journal of Economic Perspectives, 12: 139160. Accessed January 23, 2017.

Gittell, Ross and J. Phillip Thompson. 1999. "Inner City Business Development and Entrepreneurship: New Frontiers for Policy and Research." In Urban Problems and Community Development, edited by Ronald F. Ferguson and William T. Dickens, 473520. Washington DC: Brookings Institution Press.

Harrison, Bennett and Amy K. Glasmeler. 1997. "Response: Why Business Alone Won't Redevelop the Inner City: A Friendly Critique of Michael Porter's Approach to Urban Revitalization." Economic Development Quarterly 11: 28-38. Accessed April 3, 2017. Hartley, Daniel, Nikhil Kaza, and T. William Lester. 2016. "Are America's Inner Cities Competitive? Evidence from the 2000s." Economic Development Quarterly 30: 137-158. Accessed April 3, 2017. doi: 10.1177/0891242416638932.

Henrekson, Magnus and Dan Johansson. 2010. "Gazelles as Job Creators: A Survey and Interpretation of the Evidence." Small Business Economics 35: 227-244. Accessed April 3, 2017. doi: 10.1007/s11187-009-9172-z.

Imbroscio, David. 2016. "Urban Policy as Meritocracy: A Critique." Journal of Urban 
Affairs 38: 79-104. Accessed April 3, 2017. doi: 10.1111/juaf.12262.

Imbroscio, David. 2012. "Beyond Mobility: The Limits of Liberal Urban Policy." Journal of Urban Affairs 34: 1-20. Accessed April 3, 2017. doi: 10.1111/j.1467-9906.2011.00578.x.

Jacobs, Jane. 1961. The Death and Life of Great American Cities. New York: Random House.

Kirchhoff, Bruce and Bruce D. Phillips. 1988. "The Effect of Firm Formation and Growth on Job Creation in the United States." Journal of Business Venturing 3: 261-272. Accessed April 3, 2017. doi: https://doi.org/10.1016/0883-9026(88)90008-0.

Kroll, Cynthia, Diana Lee, and Nadir Shams. 2010. "The Dot-com Boom and Bust in the Context of Regional and Sectoral Changes." Industry and Innovation 17: 49-69. . Accessed April 3, 2017. doi: http://dx.doi.org/10.1080/13662710903573836.

Kunkle, Gary. 2011. "Business Establishment Employment Data: NETS versus ES-202.” Edward Lowe Foundation. http://exceptionalgrowth.org/insights/NETSvsES-202.pdf. (accessed April 3, 2017).

Lee, Barrett, Sean Reardon, Glenn Firebaugh, Chad Farrell, Stephen Matthews, and David O' Sullivan. 2008. "Beyond the Census Tract: Patterns and Determinants of Racial Segregation at Multiple Geographic Scales.” American Sociological Review 73: 766-791. Accessed April 3, 2017. doi: 10.1177/000312240807300504.

Mallach, Alan. 2015. "The Uncoupling of the Economic City: Increasing Spatial and Economic Polarization in American Older Industrial Cities." Urban Affairs Review 51: 443-473. Accessed April 3, 2017. doi: https://doi.org/10.1177/1078087414537609.

Minnesota Population Center. 2011. "National Historical Geographic Information System (NHGIS): Version 2.0.” Minneapolis: University of Minnesota. Accessed April 3, 2017. http://doi.org/10.18128/D050.V11.0. 
Neumark, David, Junfu Zhang, and Brandon Wall. 2005. Business establishment dynamics and employment growth. Hudson Institute Research Paper 05-02. https://papers.ssrn.com/sol3/papers.cfm?abstract_id=909249. (accessed April 1, 2017).

Nightingale, Paul, and Alex Coad. 2014. Muppets and Gazelles: Political and Methodological Biases in Entrepreneurship Research. Industrial and Corporate Change 23: 113-143. Accessed April 3, 2017. doi: https://doi.org/10.1093/icc/dtt057.

Nowak, Jeremy. 1997. "Neighborhood initiative and the regional economy." Economic Development Quarterly 11: 3-10. Accessed April 3, 2017. doi: https://doi.org/10.1177/089124249701100101.

O’Shea, Aidan. 2013. “How Phoenix, AZ is using transit-oriented development to reinvent downtown. Smart Growth America.” http://bit.ly/295CMko. (accessed January 23, 2017).

Pela, Robrt. 2016. 'Roosevelt Row; The Fight to Keep Downtown Phoenix 'Authentic' Is a Fight to Let it Become Something It's Never Been." Phoenix New Times. December 8, 2016. http://bit.ly/11VFxM4. (accessed January 23, 2017).

Phoenix Revitalization Corporation. 2010. Central City South Phoenix Arizona. http://bit.ly/299V8nO. (accessed January 23, 2017).

Porter, Michael 1995. "The Competitive Advantage of the Inner City." Harvard Business Review 73: 55-71.

Porter, Michael. 1997. "New Strategies for Inner City Economic Development." Economic Development Quarterly 11: 11-27. Accessed April 3, 2017. doi: https://doi.org/10.1177/089124249701100102.

Ross, Andrew. 2011. Bird on Fire. New York: Oxford University Press. 
Santarelli, Enrico and Marco Vivarelli. 2007. "Entrepreneurship and the Process of Firms' Entry, Survival and Growth." Industrial and Corporate Change 16: 455-488. Accessed April 3. doi: https://doi.org/10.1093/icc/dtm010.

Smallbone, David, Robert Baldock, and Steven Burgess. 2002. "Targeted Support for HighGrowth Start-ups: Some Policy Issues." Environment and Planning C: Government and Policy 20: 195-209. Accessed April 3, 2017. doi: https://doi.org/10.1068/c0049.

Storey, David. 1994. Understanding the Small Business Sector. London: Routledge.

Sunnucks, Mike. 2014. "Phoenix has high rate of neighborhoods declining into greater poverty." Phoenix Business Journal. December 4, 2014. http://bit.ly/29gZz19.

Talton, Jon. 2017. "In Phoenix, Signs of a Downtown That's Ready to Thrive Again." Citylab. January 3, 2017. http://bit.ly/2n5U3WV (accessed April 1, 2017).

Terrill, Marshall. 2011. "Downtown Phoenix Campus Arizona State University the First 5 Years." Arizona Board of Regents. http://www.asu.edu/firstfive/ebook.pdf. (accessed January 23, 2017).

Turner, Susan. 1997. "Barriers to a Better Break: Employer Discrimination and Spatial Mismatch in Metropolitan Detroit." Journal of Urban Affairs 19: 123-141. Accessed April 3, 2017. doi: 10.1111/j.1467-9906.1997.tb00400.x.

Von Bargen, Patrick, Doris Freedman, and Erik Pages. 2003. "The Rise of the Entrepreneurial Society." Economic Development Quarterly 17: 315-324. Accessed April 3, 2017. doi: https://doi.org/10.1177/0891242403256783.

Walls \& Associates. 2013. "National Establishment Time-Series (NETS) Database: 2012 Database Description.” Accessed January 23, 2017. http://bit.ly/297UF34. 
Welter, Friederike, Lutz Trettin, and Uwe Neumann. 2008. "Fostering Entrepreneurship in Distressed Urban Neighbourhoods." International Entrepreneurship and Management Journal 4: 109-128. Accessed April 3, 2017. doi: 10.1007/s11365-007-0069-5 


\section{Author Biographies}

Elizabeth A. Mack is an assistant professor in the Department of Geography, the Environment, and Spatial Sciences at Michigan State University. Her research is dedicated to understanding business location and economic development with an emphasis on the impacts of urban infrastructure.

Kevin Credit is a Ph.D. student in the Department of Geography, the Environment, and Spatial Sciences at Michigan State University. The overall goal of his research is to better understand how planning and urban form influence entrepreneurship, innovation, and business performance. Before beginning his doctorate, Kevin worked as a long-range planner for the City of Manhattan, Kansas. 


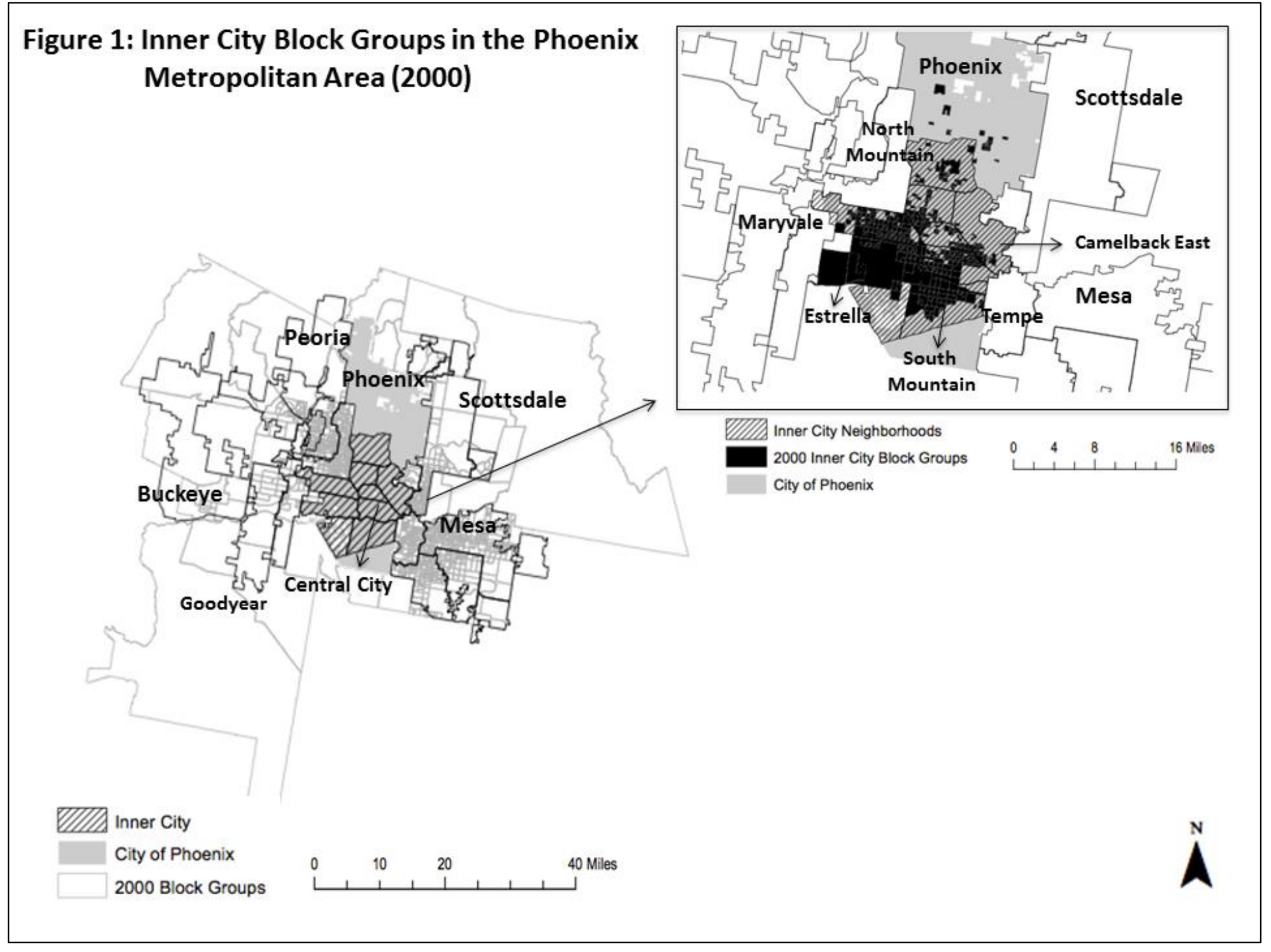




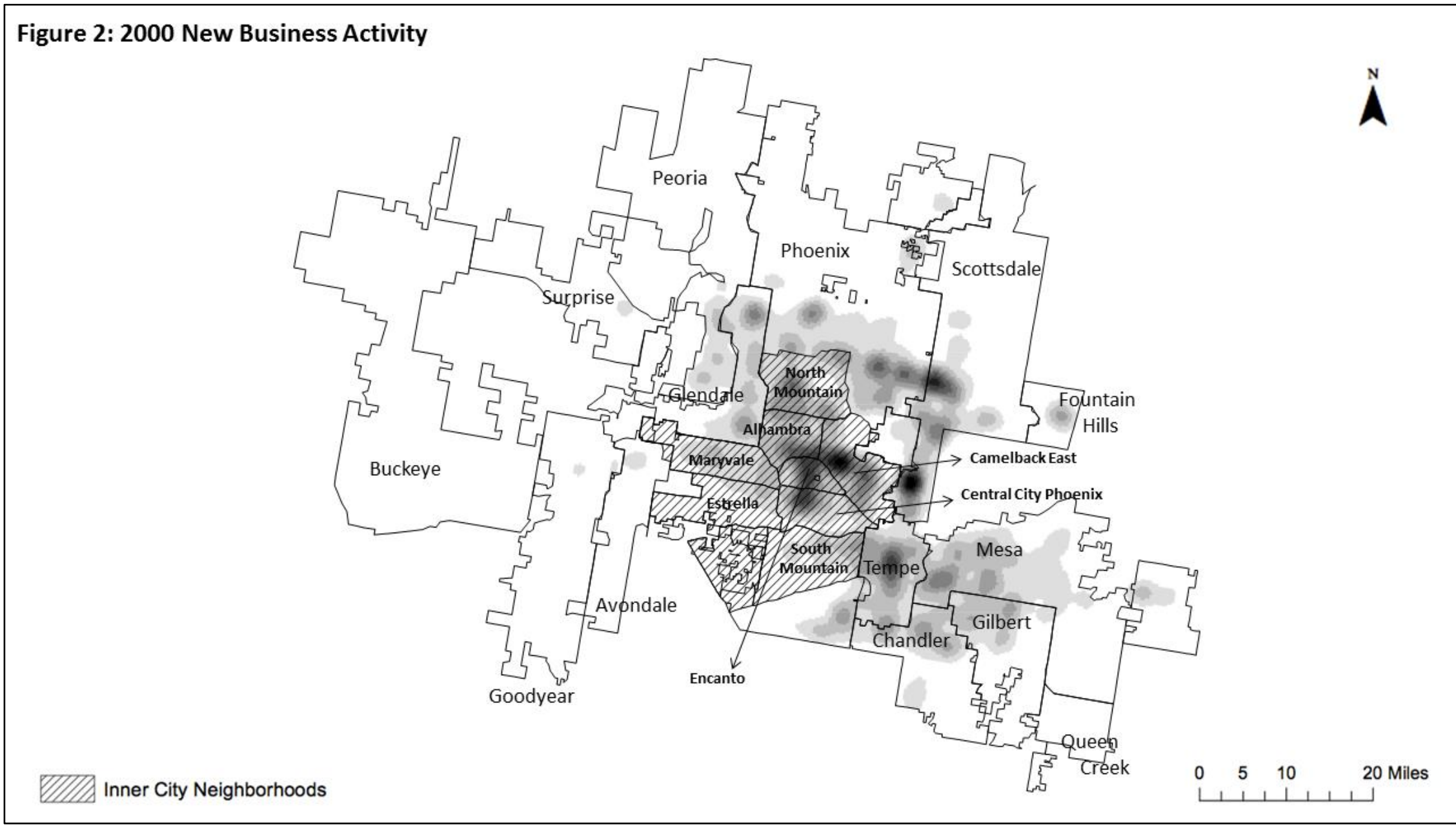




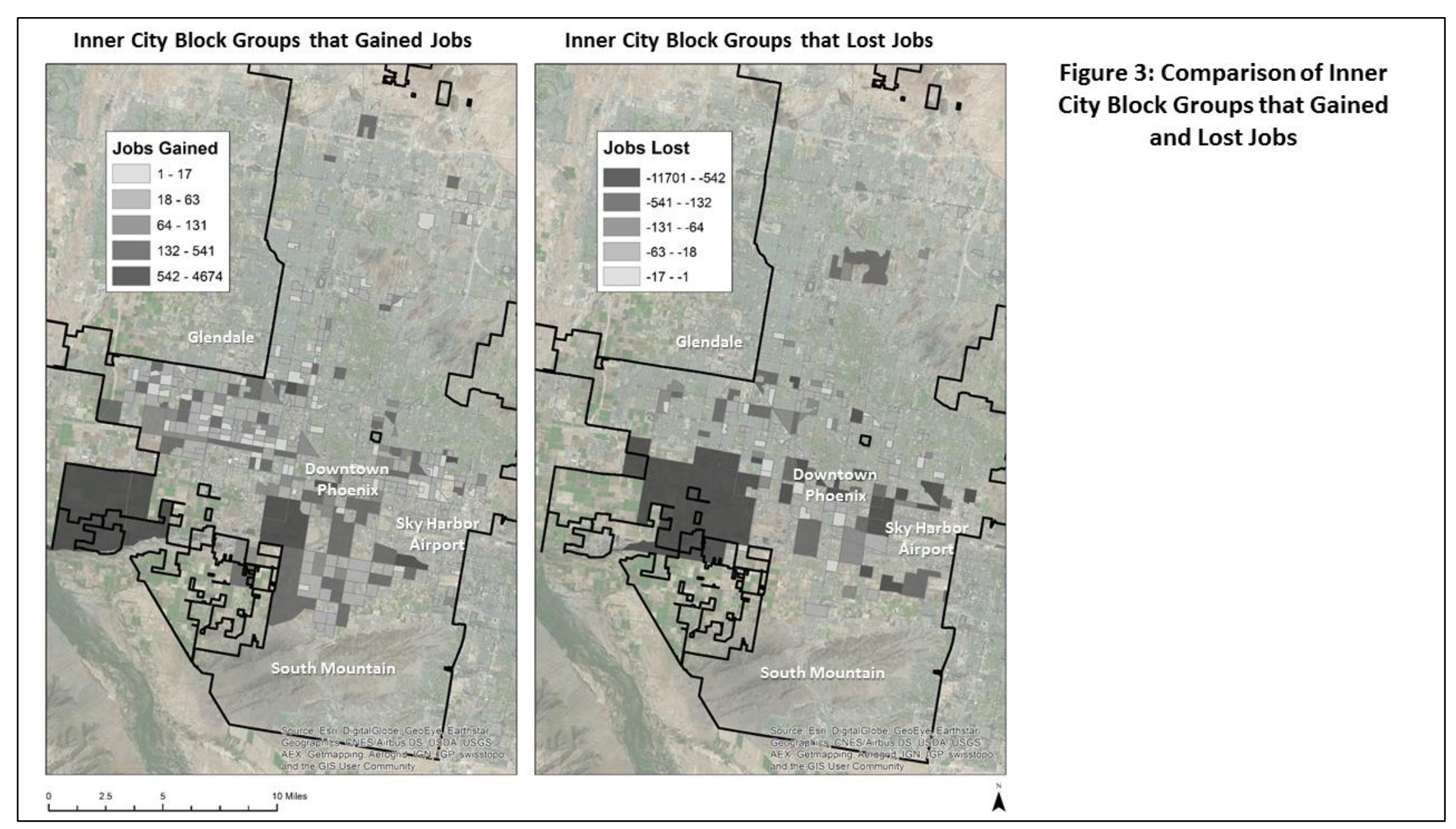




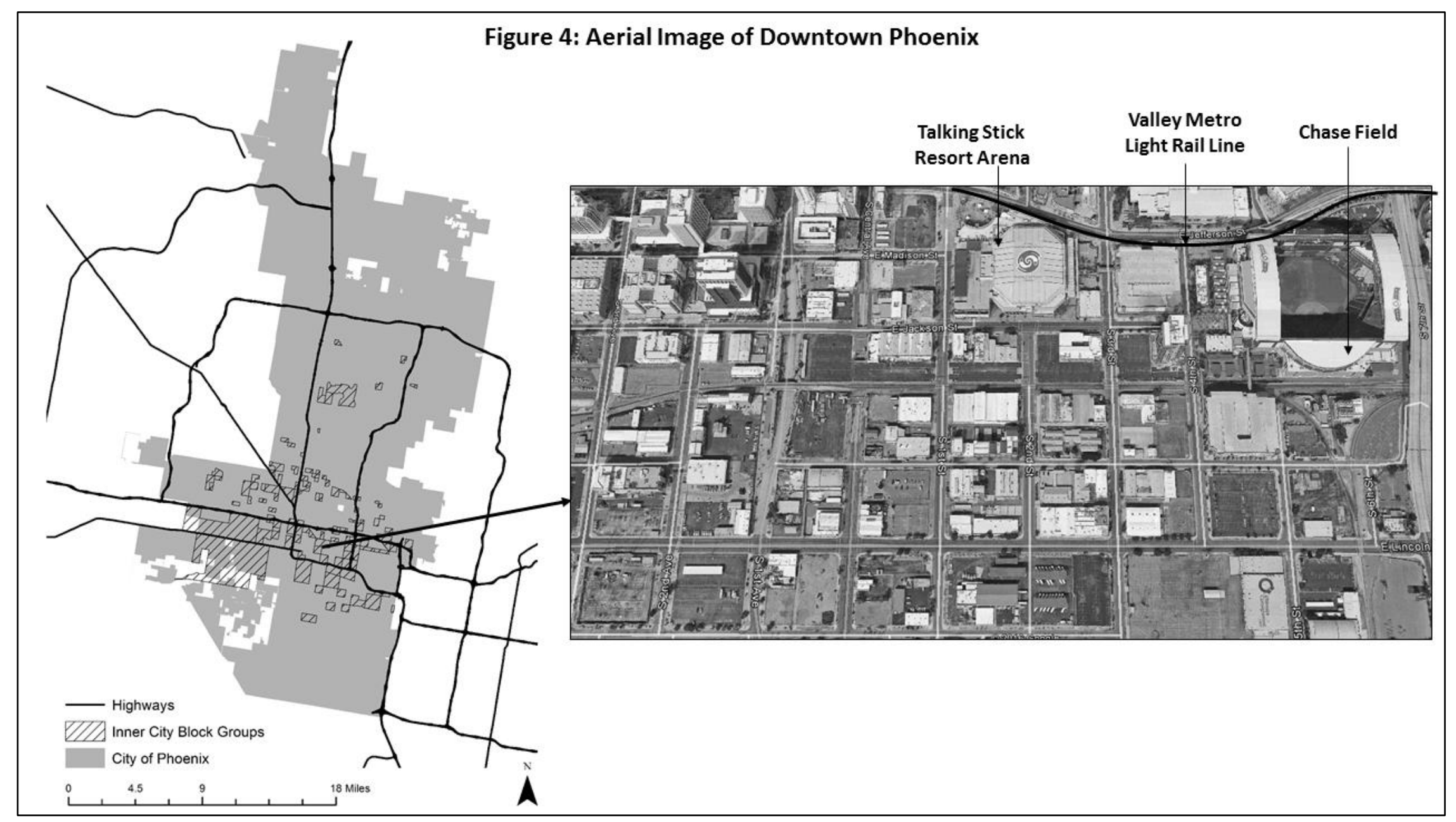


Table 1. Comparison of 2000 Block Group Characteristics.

\begin{tabular}{l|c|c} 
& Inner City & Non-Inner City \\
\hline \hline Median Population Density (Sq. Mile) & 8316.1 & 4743.5 \\
$\%$ of the Population Ages 16 to 64 & $62.3 \%$ & $64.5 \%$ \\
$\%$ White & $23.9 \%$ & $74.5 \%$ \\
$\%$ Hispanic & $63.9 \%$ & $17.1 \%$ \\
$\%$ Black & $7.0 \%$ & $2.8 \%$ \\
$\%$ Asian & $1.3 \%$ & $2.3 \%$ \\
$\%$ Bachelor's or Higher & $3.1 \%$ & $18.9 \%$ \\
Unemployment Rate & $5.3 \%$ & $2.6 \%$ \\
Median Public Assistance Income $(1999 \$)$ & $\$ 33,600$ & $\$ 3,000$ \\
Median Per Capita Income (1999\$) & $\$ 10,097$ & $\$ 21,922$ \\
Median Contract Rent & $\$ 455$ & $\$ 650$ \\
Median Year Structure Built & 1967 & 1980 \\
\hline \hline
\end{tabular}


Table 2. Description of Variables

\begin{tabular}{|c|c|c|}
\hline \multicolumn{3}{|l|}{ Dependent Variable } \\
\hline Employment Change & $\begin{array}{l}\text { Change in the natural logarithm of } \\
\text { number of employees between } 2000 \text { and } \\
2009\end{array}$ & $\begin{array}{l}\text { Author's creation from } \\
\text { NETS data }\end{array}$ \\
\hline \multicolumn{3}{|l|}{ Independent Variables of Interest } \\
\hline Spatial Lag of Employment Change & $\begin{array}{l}\text { Spatial lag of employment change } \\
\text { between } 2000 \text { and } 2009\end{array}$ & $\begin{array}{l}\text { Author's creation from } \\
\text { NETS data }\end{array}$ \\
\hline $\begin{array}{l}\text { Number of New Businesses in } 2000 \\
\text { Spatial Lag of New Businesses in } 2000\end{array}$ & $\begin{array}{l}\text { Natural logarithm of number of new } \\
\text { businesses } \\
\text { Spatial lag of new business activity in } \\
2000\end{array}$ & $\begin{array}{l}\text { Author's creation from } \\
\text { NETS data } \\
\text { Author's creation from } \\
\text { NETS data }\end{array}$ \\
\hline \multicolumn{3}{|l|}{ Controls } \\
\hline Population Density & Number of persons per square mile & $\begin{array}{l}\text { Author's creation from } 2000 \\
\text { Census data }\end{array}$ \\
\hline Median Year Structure Built & Median year structure built & 2000 Census data \\
\hline Location quotient for Black & Location quotient for Black population & $\begin{array}{l}\text { Author's creation from } 2000 \\
\text { Census data }\end{array}$ \\
\hline Location quotient for Asian & Location quotient for Asian population & $\begin{array}{l}\text { Author's creation from } 2000 \\
\text { Census data }\end{array}$ \\
\hline $\begin{array}{l}\text { Ln of Management and Professional } \\
\text { Occupations }\end{array}$ & $\begin{array}{l}\text { Natural logarithm of persons } 16 \text { years } \\
\text { and older employed in management, } \\
\text { professional, and related operations }\end{array}$ & $\begin{array}{l}\text { Author's creation from } 2000 \\
\text { Census }\end{array}$ \\
\hline Ln Vacant Developable Land & $\begin{array}{l}\text { Natural logarithm of the area of parcels } \\
\text { classified as "vacant developable" within } \\
\text { the block group }\end{array}$ & $\begin{array}{l}\text { Author's creation from } \\
\text { Maricopa Association of } \\
\text { Government's (MAG) } \\
\text { parcel data }\end{array}$ \\
\hline Ln Multifamily Land & $\begin{array}{l}\text { Natural logarithm of the area of parcels } \\
\text { classified as "multi-family" within the } \\
\text { block group }\end{array}$ & $\begin{array}{l}\text { Author's creation from } \\
\text { MAG parcel data }\end{array}$ \\
\hline $\begin{array}{l}\text { Presence of Manufacturing } \\
\text { Establishments in } 2000\end{array}$ & $\begin{array}{l}\text { Location quotient for manufacturing } \\
\text { establishments* }\end{array}$ & $\begin{array}{l}\text { Author's creation from } \\
\text { NETS data }\end{array}$ \\
\hline Establishment Diversity & $\begin{array}{l}\text { Herfindahl index computed from North } \\
\text { American Industrial Classification } \\
\text { System (NAICS) establishment data in } \\
2000^{*}\end{array}$ & $\begin{array}{l}\text { Author's creation from } \\
\text { NETS data }\end{array}$ \\
\hline
\end{tabular}

*Variables calculated using all establishment points, including relocations 
Table 3. Share of Inner City and Non-Inner City Businesses by Industry.

\begin{tabular}{|c|c|c|c|c|c|c|c|c|c|c|c|c|}
\hline & \multicolumn{4}{|c|}{ New Businesses 2000} & \multicolumn{4}{|c|}{ Existing Businesses 2000} & \multicolumn{4}{|c|}{ Existing Businesses 2009} \\
\hline & \multicolumn{2}{|c|}{ Inner City } & \multicolumn{2}{|c|}{ Non-Inner City } & \multicolumn{2}{|c|}{ Inner City } & \multicolumn{2}{|c|}{ Non-Inner City } & \multicolumn{2}{|c|}{ Inner City } & \multicolumn{2}{|c|}{ Non-Inner City } \\
\hline & No. & $\%$ & No. & $\%$ & No. & $\%$ & No. & $\%$ & No. & $\%$ & No. & $\%$ \\
\hline Agriculture, Forestry, Fishing, and Hunting (11) & 10 & $0.6 \%$ & 93 & $0.7 \%$ & 58 & $0.5 \%$ & 733 & $0.8 \%$ & 98 & $0.5 \%$ & 1676 & $0.8 \%$ \\
\hline Mining (21) & 1 & $0.1 \%$ & 13 & $0.1 \%$ & 15 & $0.1 \%$ & 110 & $0.1 \%$ & 17 & $0.1 \%$ & 148 & $0.1 \%$ \\
\hline Utilities (22) & 3 & $0.2 \%$ & 6 & $0.0 \%$ & 16 & $0.1 \%$ & 107 & $0.1 \%$ & 22 & $0.1 \%$ & 156 & $0.1 \%$ \\
\hline Construction (23) & 166 & $9.2 \%$ & 1408 & $10.1 \%$ & 945 & $7.4 \%$ & 7811 & $8.9 \%$ & 1660 & $8.1 \%$ & 17201 & $7.9 \%$ \\
\hline Manufacturing (31-33) & 104 & $5.8 \%$ & 642 & $4.6 \%$ & 1092 & $8.5 \%$ & 4570 & $5.2 \%$ & 1137 & $5.5 \%$ & 6003 & $2.7 \%$ \\
\hline Wholesale Trade (42) & 115 & $6.4 \%$ & 592 & $4.2 \%$ & 1090 & $8.5 \%$ & 4494 & $5.1 \%$ & 1370 & $6.7 \%$ & 7153 & $3.3 \%$ \\
\hline Retail Trade (44-45) & 367 & $20.3 \%$ & 2126 & $15.2 \%$ & 2062 & $16.1 \%$ & 12494 & $14.3 \%$ & 2710 & $13.2 \%$ & 17984 & $8.2 \%$ \\
\hline Transportation and Warehousing (48-49) & 83 & $4.6 \%$ & 292 & $2.1 \%$ & 490 & $3.8 \%$ & 1688 & $1.9 \%$ & 855 & $4.2 \%$ & 4004 & $1.8 \%$ \\
\hline Information $(51)$ & 41 & $2.3 \%$ & 503 & $3.6 \%$ & 250 & $2.0 \%$ & 2319 & $2.7 \%$ & 388 & $1.9 \%$ & 4067 & $1.9 \%$ \\
\hline Finance and Insurance (52) & 47 & $2.6 \%$ & 804 & $5.8 \%$ & 342 & $2.7 \%$ & 4781 & $5.5 \%$ & 815 & $4.0 \%$ & 14451 & $6.6 \%$ \\
\hline Real Estate and Rental and Leasing (53) & 94 & $5.2 \%$ & 763 & $5.5 \%$ & 800 & $6.3 \%$ & 5409 & $6.2 \%$ & 1162 & $5.6 \%$ & 12942 & $5.9 \%$ \\
\hline Professional, Scientific, and Technical Services (54) & 161 & $8.9 \%$ & 1997 & $14.3 \%$ & 1051 & $8.2 \%$ & 12125 & $13.9 \%$ & 1894 & $9.2 \%$ & 25601 & $11.7 \%$ \\
\hline Management of Companies and Enterprises (55) & 2 & $0.1 \%$ & 23 & $0.2 \%$ & 17 & $0.1 \%$ & 100 & $0.1 \%$ & 131 & $0.6 \%$ & 2666 & $1.2 \%$ \\
\hline Services (56 and 81$)$ & 379 & $21.0 \%$ & 2613 & $18.7 \%$ & 2411 & $18.9 \%$ & 15499 & $17.7 \%$ & 5744 & $27.9 \%$ & 79670 & $36.5 \%$ \\
\hline Educational Services (61) & 11 & $0.6 \%$ & 212 & $1.5 \%$ & 197 & $1.5 \%$ & 1539 & $1.8 \%$ & 266 & $1.3 \%$ & 2197 & $1.0 \%$ \\
\hline Health Care and Social Assistance (62) & 74 & $4.1 \%$ & 917 & $6.6 \%$ & 778 & $6.1 \%$ & 6623 & $7.6 \%$ & 1042 & $5.1 \%$ & 13234 & $6.1 \%$ \\
\hline Art, Entertainment, and Recreation (71) & 49 & $2.7 \%$ & 418 & $3.0 \%$ & 240 & $1.9 \%$ & 2243 & $2.6 \%$ & 320 & $1.6 \%$ & 3690 & $1.7 \%$ \\
\hline Accomodation and Food Services (72) & 85 & $4.7 \%$ & 477 & $3.4 \%$ & 782 & $6.1 \%$ & 4417 & $5.1 \%$ & 745 & $3.6 \%$ & 5144 & $2.4 \%$ \\
\hline Public Administration (92) & 15 & $0.8 \%$ & 45 & $0.3 \%$ & 154 & $1.2 \%$ & 372 & $0.4 \%$ & 222 & $1.1 \%$ & 468 & $0.2 \%$ \\
\hline Total & 1807 & $100 \%$ & 13944 & $100.0 \%$ & 12790 & $100.0 \%$ & 87434 & $100.0 \%$ & 20598 & $100.0 \%$ & 218455 & $100.0 \%$ \\
\hline
\end{tabular}


Table 4. Model Results 2000-2009.

\begin{tabular}{|c|c|c|c|}
\hline & Model 1 & Model 2 & Model 3 \\
\hline & $O L S$ & $\begin{array}{c}\text { OLS with Lag } \\
\text { New } \\
\text { Businesses }\end{array}$ & Spatial Lag \\
\hline Spatial Lag Employment Change & $\begin{array}{l}-- \\
--\end{array}$ & $\begin{array}{l}-- \\
--\end{array}$ & $\begin{array}{l}0.3550 * * \\
(0.1663)\end{array}$ \\
\hline Lag of New Business & $\begin{array}{l}-- \\
--\end{array}$ & $\begin{array}{l}0.0014 \\
0.0094\end{array}$ & $\begin{array}{l}-- \\
--\end{array}$ \\
\hline Count of New Businesses & $\begin{array}{c}-0.0282 * * * \\
(0.0059)\end{array}$ & $\begin{array}{c}-0.0282 * * * \\
(0.0059)\end{array}$ & $\begin{array}{c}-0.0295^{* * *} \\
(0.0058)\end{array}$ \\
\hline Location quotient Black & $\begin{array}{c}-0.0233 * * \\
(0.0120)\end{array}$ & $\begin{array}{c}-0.0236^{*} \\
(0.0123)\end{array}$ & $\begin{array}{l}-0.0177 \\
(0.0128)\end{array}$ \\
\hline Location quotient Asian & $\begin{array}{c}-0.0671 * * * \\
(0.0245)\end{array}$ & $\begin{array}{c}-0.0669 * * * \\
(0.0246)\end{array}$ & $\begin{array}{l}-0.0530^{*} \\
(0.0282)\end{array}$ \\
\hline Ln Vacant Developable Land (Sq Mi) & $\begin{array}{c}0.0192 \\
(0.0136)\end{array}$ & $\begin{array}{c}0.0192 \\
(0.0136)\end{array}$ & $\begin{array}{c}0.0196 \\
(0.0132)\end{array}$ \\
\hline Ln Multifamily Land (Sq Mi) & $\begin{array}{c}0.0539 * * * \\
(0.0195)\end{array}$ & $\begin{array}{c}0.0539 * * * \\
(0.0196)\end{array}$ & $\begin{array}{l}0.0384^{*} \\
(0.0211)\end{array}$ \\
\hline $\begin{array}{l}\text { Establishment Diversity (Herfindahl } \\
\text { Index) }\end{array}$ & $\begin{array}{c}1.4346^{* * *} \\
(0.4005)\end{array}$ & $\begin{array}{c}1.437 * * * \\
(0.3995)\end{array}$ & $\begin{array}{c}1.2426^{* * * *} \\
(0.4143)\end{array}$ \\
\hline $\begin{array}{l}\text { Location quotient Manufacturing } \\
\text { Businesses }\end{array}$ & $\begin{array}{l}-0.0002 \\
(0.0378)\end{array}$ & $\begin{array}{c}0.0002 \\
(0.0374)\end{array}$ & $\begin{array}{l}-0.0070 \\
(0.0399)\end{array}$ \\
\hline Population Density 2000 & $\begin{array}{c}2.56 \mathrm{E}-05^{* * * *} \\
(6.66 e-06)\end{array}$ & $\begin{array}{l}2.55 \mathrm{E}-05^{* * *} \\
(6.81 e-06)\end{array}$ & $\begin{array}{c}2.21 \mathrm{E}-05^{* * * *} \\
(6.50 e-06)\end{array}$ \\
\hline Median Year Structure Built & $\begin{array}{l}-0.0002 \\
(0.0005)\end{array}$ & $\begin{array}{l}-0.0002 \\
(0.0005)\end{array}$ & $\begin{array}{l}-0.0002 \\
(0.0005)\end{array}$ \\
\hline $\begin{array}{l}\text { Ln Management and Professional } \\
\text { Occupations }\end{array}$ & $0.1294 * * *$ & $0.1299 * * *$ & $0.0883^{* *}$ \\
\hline Constant & $\begin{array}{c}(0.0375) \\
0.5217 \\
(0.9773) \\
\end{array}$ & $\begin{array}{c}(0.0381) \\
0.5111 \\
(0.9466) \\
\end{array}$ & $\begin{array}{c}(0.0439) \\
0.5332 \\
(0.9111) \\
\end{array}$ \\
\hline $\begin{array}{l}\text { Adj R-Squared } \\
\text { Spatial Pseudo R-Squared } \\
\text { Degrees Freedom } \\
\text { Root MSE }\end{array}$ & $\begin{array}{c}0.2273 \\
-- \\
359 \\
0.70945\end{array}$ & $\begin{array}{c}0.2252 \\
-- \\
358 \\
0.7104\end{array}$ & $\begin{array}{c}-- \\
0.258 \\
358 \\
--\end{array}$ \\
\hline
\end{tabular}


Table 5. Results of ANOVA Analysis.

\begin{tabular}{l|c|c|c} 
& Gained Jobs & Lost Jobs & Significance \\
\hline \hline LQ Manufacturing Establishments & 0.90 & 1.13 & $10 \%$ \\
Vacant Developable Land (Sq Mi) & 0.02 & 0.04 & $10 \%$ \\
Multifamily Land (Sq Mi) & 0.01 & 0.02 & $5 \%$ \\
Establishment Diversity & 0.21 & 0.17 & $1 \%$ \\
Count New Business Activity & 3.28 & 9.11 & $1 \%$ \\
Median Contract Rent (1999\$) & 459.26 & 425.96 & $5 \%$ \\
Location quotient Retail & & & \\
Establishments & 1.12 & 1.24 & Not significant \\
Location quotient Black & 1.89 & 1.94 & Not significant \\
Location quotient Asian & 0.57 & 0.58 & Not significant \\
Location quotient Hispanic & 2.49 & 2.46 & Not significant \\
Single Family Land (Sq Mi) & 0.09 & 0.07 & Not significant \\
\% Bachelor's degree or higher & $6.0 \%$ & $6.2 \%$ & Not significant \\
\% Population ages 16 to 64 & $60.2 \%$ & $61.8 \%$ & Not significant \\
Public Assistance Income (1999\$) & 58006.51 & 57640.00 & Not significant \\
Per Capita Income (199\$) & 9830.76 & 9747.29 & Not significant \\
\hline \hline
\end{tabular}


Appendix A. Descriptive Statistics.

\begin{tabular}{l|c|c|c|c|c} 
& Obs & Mean & Std. Dev. & Min & Max \\
\hline \hline Lag of New Business & 370 & 4.00 & 4.13 & 0 & 30 \\
Count of New Businesses & 370 & 4.91 & 8.74 & 0 & 73 \\
Location quotient Black & 370 & 1.90 & 2.59 & 0 & 24 \\
Location quotient Asian & 370 & 0.57 & 1.16 & 0 & 8.6 \\
Ln Vacant Developable Land (Sq Mi) & 370 & -3.80 & 2.56 & -8.62 & 0.34 \\
Ln Multi-Family Land (Sq Mi) & 370 & -3.11 & 2.24 & -8.07 & 0 \\
Establishment Diversity (Herfindahl Index) & 370 & 0.21 & 0.15 & 0 & 1 \\
LQ Manufacturing Businesses & 370 & 0.96 & 1.17 & 0 & 5 \\
Population Density 2000 & 370 & 8757.52 & 5585.76 & 0 & 35208.3 \\
Median Year Structure Built & 370 & 1930 & 269 & 0 & 1993 \\
Ln Management and Professional & 370 & 3.67 & 1.21 & 0 & 5.7 \\
Occupations & & &
\end{tabular}


Appendix B. Model Results for Employment Change 2000-2007.

\begin{tabular}{|c|c|c|c|}
\hline & Model 1 & Model 2 & Model 3 \\
\hline & $O L S$ & OLS with Lag NS & Spatial Lag \\
\hline \multirow[t]{2}{*}{ Spatial Lag Employment Change } & +- & -- & 0.2782 \\
\hline & -- & -- & 0.1762 \\
\hline \multirow[t]{2}{*}{ Lag of New Business } & -- & 0.004 & -- \\
\hline & -- & $(0.8419)$ & -- \\
\hline Count of New Businesses & $\begin{array}{c}-0.0217 * * * \\
(0.0056)\end{array}$ & $\begin{array}{c}-0.0218 * * * \\
(0.0056)\end{array}$ & $\begin{array}{c}-0.0228 * * * \\
(0.0056)\end{array}$ \\
\hline Location quotient Black & $\begin{array}{r}-0.0209 * \\
(0.0117)\end{array}$ & $\begin{array}{l}-0.0216^{*} \\
(0.0119)\end{array}$ & $\begin{array}{l}-0.0170 \\
(0.0118)\end{array}$ \\
\hline Location quotient Asian & $\begin{array}{c}-0.0568 * * * \\
(0.0202)\end{array}$ & $\begin{array}{c}-0.0564 * * * \\
(0.0203)\end{array}$ & $\begin{array}{c}-0.0503 * * \\
(0.0236)\end{array}$ \\
\hline Ln Vacant Developable Land (Sq Mi) & $\begin{array}{c}0.0204 \\
(0.0126)\end{array}$ & $\begin{array}{c}0.0205 \\
(0.0126)\end{array}$ & $\begin{array}{l}0.0219^{*} \\
(0.0122)\end{array}$ \\
\hline Ln Multifamily Land (Sq Mi) & $\begin{array}{l}0.0329 * \\
(0.0175)\end{array}$ & $\begin{array}{l}0.0329 * \\
(0.0175)\end{array}$ & $\begin{array}{c}0.0247 \\
(0.0184)\end{array}$ \\
\hline \multirow[t]{2}{*}{$\begin{array}{l}\text { Establishment Diversity (Herfindahl } \\
\text { Index) }\end{array}$} & $1.3629 * * *$ & $1.3700 * * *$ & $1.2316^{* * *}$ \\
\hline & $(0.3750)$ & $(0.3750)$ & $(0.3864)$ \\
\hline \multirow[t]{2}{*}{$\begin{array}{l}\text { Location quoteint Manufacturing } \\
\text { Businesses }\end{array}$} & -.00533 & -0.0042 & -0.0088 \\
\hline & $(0.0359)$ & $(0.0357)$ & $(0.0386)$ \\
\hline Population Density 2000 & $\begin{array}{l}1.70 \mathrm{E}-05^{* * * *} \\
(5.67 e-06)\end{array}$ & $\begin{array}{l}1.66 \mathrm{E}-05^{* * *} \\
(5.83 e-06)\end{array}$ & $\begin{array}{c}1.51 \mathrm{E}-05^{* * *} \\
(5.50 e-06)\end{array}$ \\
\hline Median Year Structure Built & $\begin{array}{c}0.0000994 \\
(0.0004)\end{array}$ & $\begin{array}{c}0.0000966 \\
(0.0004)\end{array}$ & $\begin{array}{l}-0.0001 \\
(0.0004)\end{array}$ \\
\hline \multirow[t]{2}{*}{$\begin{array}{l}\text { Ln Management and Professional } \\
\text { Occupations }\end{array}$} & $0.1032 * * *$ & $0.1048^{* * *}$ & $0.0764 *$ \\
\hline & $(0.0344)$ & $(0.0348)$ & $(0.0398)$ \\
\hline Constant & $\begin{array}{c}0.3719546 \\
(0.8713)\end{array}$ & $\begin{array}{r}0.3406 \\
(0.8419) \\
\end{array}$ & $\begin{array}{c}0.3822 \\
(0.8399)\end{array}$ \\
\hline Adj R-Squared & 0.1921 & 0.1904 & "-- \\
\hline Spatial Pseudo R-Squared & -- & -- & 0.2192 \\
\hline Degrees Freedom & 359 & 358 & 358 \\
\hline Root MSE & 0.6438 & 0.6445 & -- \\
\hline
\end{tabular}


Appendix C. Model Results for Employment Change 2000-2005.

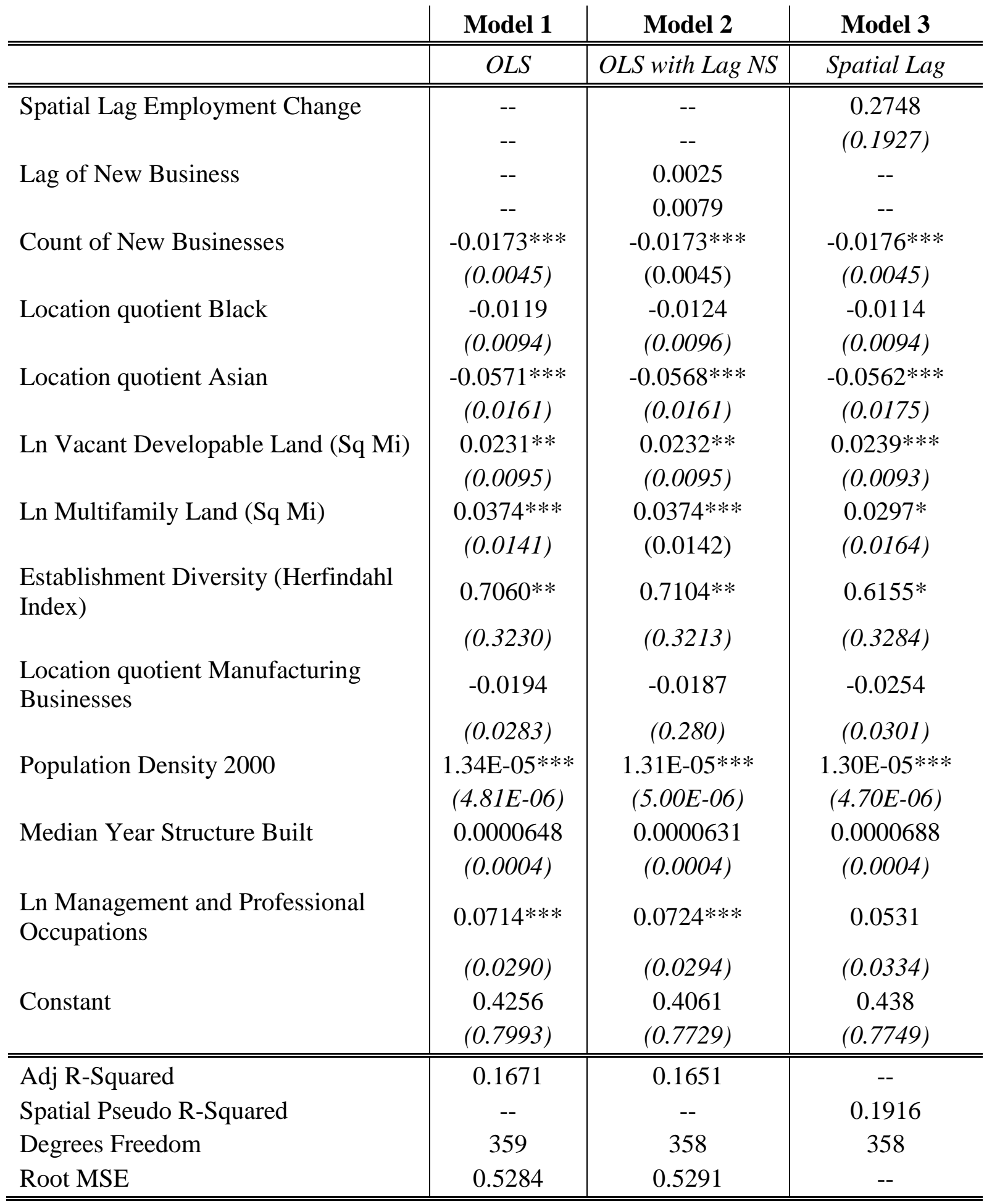

